\title{
Construction and validation of a podcast for dental surgeons: timely conduction after
}

\section{tooth avulsion}

Construção e validação de um podcast para cirurgiões dentistas: condução oportuna após avulsão dentária

Construcción y validación de un podcast para cirujanos dentales: conducción oportuna después de la avulsión de diente

Keylla Cação Fernandes ORCID: https://orcid.org/0000-0002-2940-6878 Universidade do Estado do Amazonas, Brasil E-mail: kcf.tis19@uea.edu.br

Elielza Guerreiro Menezes

ORCID: https://orcid.org/0000-0003-1804-6384 Universidade do Estado do Amazonas, Brasil E-mail: egmenezes@uea.edu.br

Lihsieh Marrero

ORCID: https://orcid.org/0000-0002-2856-5682 Universidade do Estado do Amazonas, Brasil E-mail: 1mmarrero@uea.edu.br

Milena Batista de Oliveira

ORCID: https://orcid.org/0000-0002-7003-7269 Universidade do Estado do Amazonas, Brasil E-mail: mbo.enf17@uea.edu.br

\begin{abstract}
Objective: Create and validate a podcast for dental surgeons as a guide after a dental avulsion. The validation was done through Google forms. Nine expert judges participated, following four aspects: characterization of the judges, content, functionality and appearance. The quantitative analysis was performed with Excel software to calculate the content validity index. Method: Methodological study with a quantitative and validation approach, carried out in three stages: integrative review of the literature; technology construction; validation of a post-avulsion podcast presented to nine expert judges. A Likert scale was used for data collection. For the analysis, a content validity index $\geq 0.75$ was adopted. Results: The Content Validity Index presented values of $0.84 \%$ in its structure and presentation, $099 \%$ of high relevance for expert judges. Conclusion: The "Al Dente" podcast contains important information on dental reimplantation after an avulsion, resulting in preventive measures that directly influence health services.
\end{abstract}

Keywords: Tooth avulsion; Tooth replantation; Educational technology; Dentistry.

\section{Resumo}

Objetivo: Construir e validar um podcast para cirurgiões-dentistas para orientações após uma avulsão dentária. A validação ocorreu via Google Forms. Participaram nove juízes especialistas, seguindo quatro aspectos: caracterização dos juízes, conteúdo, funcionalidade e aparência. A análise quantitativa foi realizada no software Excel para calcular Índice de Validade de Conteúdo. Método: Estudo metodológico com abordagem quantitativa e de validação, realizado em três etapas: revisão integrativa da literatura; construção da tecnologia; validação de um podcast pós avulsão dentária submetido à apreciação de nove juízes especialistas. Na coleta de dados utilizou-se uma escala de Likert. Para análise, adotaram-se Indice de Validade de Conteúdo $\geq 0,75$. Resultados: O Índice de Validade de Conteúdo apresentou valores de $0,84 \%$ na sua estrutura e apresentação, $099 \%$ de alta relevância para os juízes especialistas. Conclusão: o podcast "Al Dente" tem informações importantes sobre reimplante dentário após uma avulsão, resultando em medidas preventiva que influenciam diretamente nos serviços de saúde.

Palavras-chave: Avulsão dentária; Reimplante dentário; Tecnologia educacional; Odontologia.

\section{Resumen}

Objetivo: Crear y validar un podcast para cirujanos dentales como guía después de una avulsión dental. La validación se realizó a través de formularios de Google. Participaron nueve jueces expertos, siguiendo cuatro aspectos: caracterización de los jueces, contenido, función y apariencia. El análisis cuantitativo se realizó con el software Excel para calcular el índice de validez del contenido. Método: Estudio metodológico con enfoque cuantitativo y de 
validación, realizado en tres etapas: revisión integradora de la literatura; construcción de tecnología; validación de un podcast posterior a la avulsión dental presentado a nueve jueces expertos. Para la recolección de datos se utilizó una escala Likert. Para el análisis, se adoptó un índice de validez de contenido $\geq 0,75$. Resultados: El Índice de Validez de Contenido presentó valores de $0.84 \%$ en su estructura y presentación, $099 \%$ de alta relevancia para jueces expertos. Conclusión: el podcast "Al Dente" contiene información importante sobre la reimplantación dental después de una avulsión, lo que resulta en medidas preventivas que influyen directamente en los servicios de salud.

Palabras clave: Avulsión de diente; Reimplante dental; Tecnología educacional; Odontología.

\section{Introduction}

Dental traumas are emergency situations, which often occur in dental clinics and hospitals. Dental surgeons, as well as health professionals, should be familiar and prepared with different factors that can influence the correct prognosis of dental reimplantation (Andreasen, 2018; Jain et al. 2017).

A tooth avulsion is a type of serious injury that causes damage to tooth structures that can be irreversible. It is defined as a total displacement of the tooth out his alveolus, where it compromises cement, periodontal ligament, alveolar bone, gum and pulp. Disfavoring the masticatory, phonetic, aesthetic functions, occlusion, loss of space in the dental arch, as well as psychological (Andreasen, 2018).

Different causes can generate a dental trauma: road accidents, contact sports, aggression, falls, collisions (Mesquita; Silva, 2017), emergency intubation practiced in hospitals (Galvão et al. 2020).

The public in which these traumas occur the most, are young male patients, mainly reaching the upper central incisors (Andreasen, 2018; Jain et al. 2017; Mesquita et al. 2017).

The main factors that can change the prognosis are: the time outside of the alveolus, the ways of conservation of the dental element and the stage of root development (Andreasen, 2018). Knowledge about trauma by numerous health professionals is essential, since the success in the immediate reimplantation procedure it will contribute considerably to the maintenance of the dental element in its own place (Andreasen, 2018; Galvão et al. 2020).

Public and educational policies should be implemented in order to provide information about dental reimplantation. It is expected that the combination of preventive and educational actions will decrease the rates of avulsion accidents and improve the prognosis in long terms of reimplanted teeth (Mesquita et al. 2017).

A validated study using information and Communication Technologies (ICTs) in education has proved to be something indispensable in the teaching and learning process. The podcast it's a tool with considerable capacity and potential to be used in teaching and promoting information (Vianna et al. 2018).

According to the State of the Podcast Universe report in june 2020, published by Voxnest, an American company focused on data studies involving on the creation and distribution of podcasts, Brazil leads the ranking of countries where the production of content of the genre has grown the most since the beginning of 2020, behind of Turkey, India, Colombia and Argentina.

Given the great importance of this topic, dental surgeons should be aware of their role in preventing and assisting in cases of dental avulsion, since the prompt care and the indication of an appropriate treatment directly influence the success of the reimplantation. Thus, it was defined as the objective of the study to build and validate a podcast for dental surgeons with guidance after a Tooth avulsion.

\section{Method}

Methodological study with quantitative and validation approach. This type of research seeks the development, evaluation and improvement of methodological instruments and strategies (Polit \& Beck, 2011). The technology was the 
product of the project developed by the Program of Technology and innovation in health of the State University of Amazonas, developed under the Laboratory of Technology in health and education-LABTECS, held in the period from August 2020 to March 2021, with the participation of four health professionals with university degree.

The study was conducted in three phases: integrative literature review, technology construction, and content validation.

\section{Step 1-Integrative literature review}

An integrative literature review was carried out, which began with the definition of a problem and the formulation of the research question using for the elaboration of the problem/question the PICo strategy, acronym for Population, Interest, Context.

Thus, the question is: What level of knowledge that the Thus, the question is: What is the level of knowledge that dental surgeons have about dental replantation after tooth avulsion? have about dental reimplantation after a dental avulsion?

To answer the guiding question of the review, a search was performed through the Virtual Health Library (VHL), in the databases Scientific Electronic Library Online (SciELO), Latin American and Caribbean Literature in Health Sciences (LILACS) and National Library of Medicine (PubMed) by crossing the following controlled descriptors: (MESH) [Tooth Avulsion] and [Tooth Replantation].

Through these descriptors, we proceeded to analyze the studies, excluding those not consistent with the criteria and the proposal of the research, as well as repeated articles. The inclusion criteria were studies that suited articles with full text, articles that deal with the topic and published in the last 5 years (2016 to 2020).

After the process of filtering the studies, the analysis was used through the phases of research such as database survey, exploration of the material, selective reading verifying the adequacy of the article with the study theme. The selection of the articles was conducted in flowchart format with details according to the Preferref reporting Items for Systematic Review and Meta-Analyses (PRISMA) methodology. In this step, 229 publications were found for analysis, of which, after reading the abstracts, 20 articles were selected for reading in full. (Figure 1) presents the synthesis of the results obtained in each step: 
Figure 1: Flowchart of the selection of articles for the study of Integrative review by PRISMA. Manaus-AM, 2021.
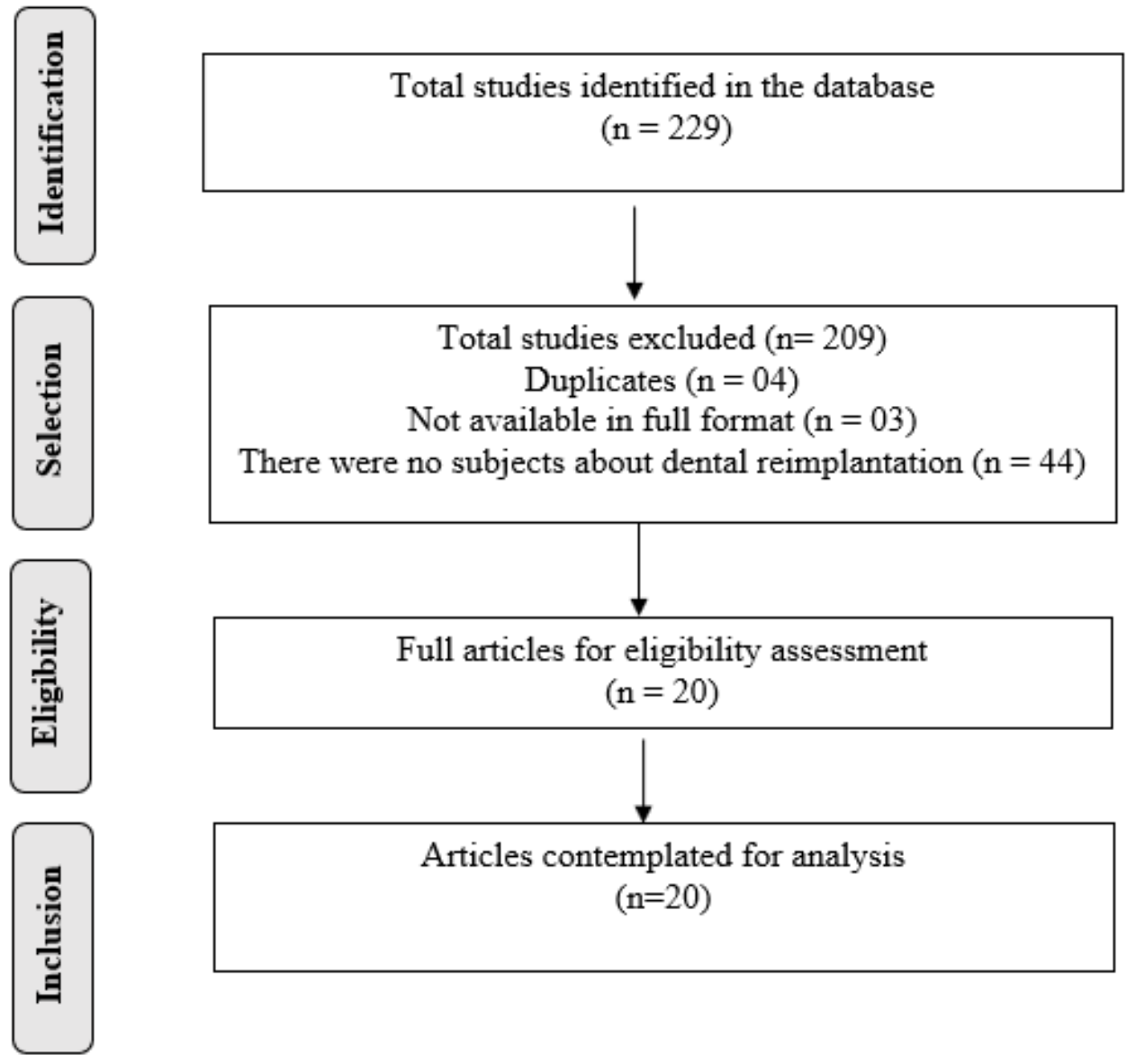

Source: Authors.

\section{Step 2 - Technology Development, editing and diagramming}

Based on the exhaustive reading, the generating themes directly related to dental avulsion were listed, they were organized according to the frequency of citation in the articles and it was found that it was convergent with the themes that emerged in the first phase. The themes were developed and organized to select illustrations for each of the themes that helped in the construction of the podcast according to the guidelines of the International Association of Dental Traumatology (IADT) (2020). It was then built a Podcast called "Al Dente", developed in the myriad of audio recording and editing software, specifically in Adobe Premiere ${ }^{\circledR}$ Pro CC 2020 version 2020, a microphone model XO-MKF 03 with 11 minutes of duration.

\section{Step 3 - Content Validation}

In this step, the content validation was carried out by expert judges. They were considered judges of the area of dentistry, dental surgeons with experience and degree of knowledge in the subject. Searches were carried out on the Lattes platform of the National Council for Scientific and technological development (CNPq) to verify the adequacy of possible participants to the inclusion criteria. Of the 11 judges initially chosen, 9 composed this survey. Specialists who did not comply with the deadline for acceptance stipulated by the researchers were excluded.

Through formal contact by e-mail, it occurred through an invitation letter exposing the reason why he was chosen, the purpose of the study and how his participation would be given. Those who agreed to participate were sent the free and informed consent form (TCLE) along with the content validation form. The instruments were sent in electronic form through 
the Google form ${ }^{\circledR}$ creation application, being viewed and filled out online. For this purpose, the content validity Index (CVI) was used.

The expert judges received a version of the technology and the instrument containing the content validity index (CVI) using the Likert scale. The period of Return of the material ranged from 3 to 10 days. The Content Validity Index (CVI) was used, which measures the proportion or percentage of judges who agree with certain aspects of the instrument and its items. It initially allows analyzing each item individually and then the instrument as a whole (Pasquali, 2017; Suganya et al. 2017).

The study respected the determinations of Resolution No. 466/12 of the National Health Council. The project is part of the macro-project "development and validation of interactive technologies in health and education in human care innovation" approved by the Research Ethics Committee (CEP) of the State University of Amazonas under the number ${ }^{\circ}$ 3.574.288 and $\mathrm{n}^{\circ \circ} 15924919.6 .0000 .5016$.

\section{Results}

The selected publications of the 20 articles to identify the level of knowledge of health professionals about dental reimplantation after an avulsion are described in (Chart 1).

Chart 1 - Description of publications according to year of publication, authors, objective and findings. Manaus-AM, 2021.

\begin{tabular}{|c|c|c|c|}
\hline Year & Author & Objective & Result \\
\hline 2020 & $\begin{array}{l}\text { Rodrigues OF, Landim, KLG, } \\
\text { Alves RT, Machado FC, } \\
\text { Carrada CF }\end{array}$ & $\begin{array}{l}\text { Evaluate the knowledge of health } \\
\text { graduates about avulsion of permanent } \\
\text { teeth. }\end{array}$ & $\begin{array}{l}\text { When comparing the students of the programs of } \\
\text { Dentistry, Nursing and medicine regarding the } \\
\text { learning about avulsion of permanent teeth, the } \\
\text { students of Dentistry had more knowledge about } \\
\text { the subject, but in the practical experience it was } \\
\text { considered low. }\end{array}$ \\
\hline 2020 & Duruk G, Erel ZB & $\begin{array}{l}\text { Evaluate the knowledge of general } \\
\text { dentists and specialists on the } \\
\text { management of avulsified teeth. }\end{array}$ & $\begin{array}{l}\text { Pediatric dentists had better knowledge about } \\
\text { dental avulsion, compared to other specialists in } \\
\text { the dental area. }\end{array}$ \\
\hline 2020 & $\begin{array}{l}\text { Sen Yavuz B, Sadikoglu S, } \\
\text { Sezer B, Toumba J, Kargul B }\end{array}$ & $\begin{array}{l}\text { Investigate the knowledge and attitudes of } \\
\text { general dentists about the emergency } \\
\text { management of avulsified teeth. }\end{array}$ & $\begin{array}{l}\text { The results show that many professionals had } \\
\text { limited experience in the treatment of avulsified } \\
\text { teeth. }\end{array}$ \\
\hline 2020 & Aras A, Dogan MS & $\begin{array}{l}\text { Assess the attitudes of emergency } \\
\text { technicians, doctors and paramedics } \\
\text { towards dental trauma and their levels of } \\
\text { knowledge about the subject. }\end{array}$ & $\begin{array}{l}\text { Doctors and paramedics did not have enough and } \\
\text { accurate information about dentin trauma. The } \\
\text { lack of knowledge about dentin trauma prevents } \\
\text { rapid and accurate intervention in cases. }\end{array}$ \\
\hline 2019 & $\begin{array}{l}\text { Kariya P, Singh S, Bargale S, } \\
\text { Shah S, Kulkarni N, Dave B }\end{array}$ & $\begin{array}{l}\text { Evaluate the knowledge of general } \\
\text { dentists about the emergency management } \\
\text { of dental trauma that leads to avulsion in } \\
\text { children. }\end{array}$ & $\begin{array}{l}\text { The Discovery justifies the need for informative } \\
\text { educational programs to update and increase } \\
\text { dentists knowledge regarding emergency } \\
\text { management of avulsified teeth }\end{array}$ \\
\hline 2019 & Calle TP, Vélez KP & $\begin{array}{l}\text { Determine the degree of knowledge about } \\
\text { the management of dental avulsion of a } \\
\text { representative group of dentists from the } \\
\text { city of Cuenca, Ecuador. }\end{array}$ & $\begin{array}{l}\text { Most of the participating dentists have } \\
\text { insufficient knowledge about the management of } \\
\text { dental avulsion, unlike the dentistry specialists of } \\
\text { the surveyed population; the latter are clearly } \\
\text { better able to control this lesion. }\end{array}$ \\
\hline
\end{tabular}




\begin{tabular}{|c|c|c|c|}
\hline 2019 & $\begin{array}{l}\text { Sari SA, Kowash M, Hussein } \\
\text { I, Halabi MA }\end{array}$ & $\begin{array}{l}\text { Evaluate the knowledge of nurses and } \\
\text { physical education teachers about } \\
\text { emergency management of traumatic } \\
\text { dental injuries (TDIs) in schools and } \\
\text { measure the impact of education on their } \\
\text { knowledge. }\end{array}$ & $\begin{array}{l}\text { There was a noticeable improvement in the } \\
\text { general knowledge score on TDIs throughout the } \\
\text { study, especially after the educational session. } \\
\text { This improvement was observed and sustained. }\end{array}$ \\
\hline 2019 & $\begin{array}{l}\text { França AB, Neves ACS, } \\
\text { Queiroz AF, Poi WR, Hidalgo } \\
\text { MM }\end{array}$ & $\begin{array}{l}\text { Evaluate the knowledge of dental } \\
\text { surgeons from the city of Maringá, State } \\
\text { of Paraná, Brazil, about the management } \\
\text { of avulsified teeth. }\end{array}$ & $\begin{array}{l}\text { They did not demonstrate good knowledge about } \\
\text { the procedures to be adopted for the management } \\
\text { of avulsified teeth. Misunderstandings regarding } \\
\text { the appropriate method of storage and } \\
\text { immobilization were observed. }\end{array}$ \\
\hline 2018 & Bahammam LA & $\begin{array}{l}\text { Evaluate the knowledge of emergency } \\
\text { room doctors with different specialties, } \\
\text { experience and hospital sectors for the } \\
\text { management of avulsified teeth eight } \\
\text { major hospitals in Jeddah, Saudi Arabia. }\end{array}$ & $\begin{array}{l}\text { This study revealed that most emergency room } \\
\text { doctors do not have the necessary knowledge to } \\
\text { manage cases of dental avulsions. }\end{array}$ \\
\hline 2018 & $\begin{array}{l}\text { Zafar K, Ghafoor R, Khan } \\
\text { FR, Hameed MH }\end{array}$ & $\begin{array}{l}\text { Evaluate the knowledge of dentists in } \\
\text { relation to the immediate management of } \\
\text { dental avulsion. }\end{array}$ & $\begin{array}{l}\text { The dentists interviewed had inadequate } \\
\text { knowledge. Knowledge was significantly } \\
\text { associated with the specialty and qualification of } \\
\text { the dentist. }\end{array}$ \\
\hline 2018 & $\begin{array}{l}\text { Nagata JY, Góis VLA, } \\
\text { Munchow EA, Albuquerque } \\
\text { MTP }\end{array}$ & $\begin{array}{l}\text { Investigate the effect of educational } \\
\text { intervention in dental trauma among } \\
\text { undergraduate students of a Federal } \\
\text { University of Brazil. }\end{array}$ & $\begin{array}{l}\text { The educational intervention demonstrated a } \\
\text { significant positive impact on the knowledge of } \\
\text { dental trauma emergency management among } \\
\text { health students. }\end{array}$ \\
\hline 2018 & $\begin{array}{l}\text { Alaslami RA, Elshamy FMM, } \\
\text { Maamar EM, Ghazwani YH }\end{array}$ & $\begin{array}{l}\text { Assess awareness among dentists working } \\
\text { in Jazan about their potential role in the } \\
\text { treatment of traumatic dental avulsion } \\
\text { injuries. }\end{array}$ & $\begin{array}{l}\text { A statistically significant result was observed in } \\
\text { relation to the best storage medium. Very } \\
\text { important for successful reimplantation is the } \\
\text { management of the tooth before reimplantation. }\end{array}$ \\
\hline 2017 & $\begin{array}{l}\text { Iver SS, } \underline{\text { Panigrahi }} \mathrm{A}, \underline{\text { Sharma }} \\
\text { S }\end{array}$ & $\begin{array}{l}\text { Evaluate the knowledge and awareness of } \\
\text { doctors and nurses about first aid in dental } \\
\text { avulsion. }\end{array}$ & $\begin{array}{l}\text { The results suggested a definitive inadequacy in } \\
\text { knowledge. }\end{array}$ \\
\hline 2017 & $\begin{array}{l}\text { Mesquita GC, Soares PBF, } \\
\text { Moura CCG, Roscoe MG, } \\
\text { Paiva SM, Soares CG }\end{array}$ & $\begin{array}{l}\text { Evaluated the epidemiological and } \\
\text { management characteristics of cases of } \\
\text { avulsion of permanent teeth attended in a } \\
\text { dental trauma service from December } \\
2005 \text { to August } 2016 \text {. }\end{array}$ & $\begin{array}{l}\text { Several avulsified teeth were handled } \\
\text { inadequately and immediate re-implantation was } \\
\text { not frequent. }\end{array}$ \\
\hline 2017 & $\begin{array}{l}\text { Suganya M, Vikneshan M, } \\
\text { Hiremath A }\end{array}$ & $\begin{array}{l}\text { Evaluate the knowledge and awareness of } \\
\text { active nurses and trainees regarding the } \\
\text { emergency management of dental } \\
\text { traumatic injuries. }\end{array}$ & $\begin{array}{l}\text { The nurses evaluated have less knowledge than } \\
\text { expected. }\end{array}$ \\
\hline 2017 & $\begin{array}{l}\text { Jokic NI, Bakarcic D, Grzic } \\
\text { R, Majstorovic M, Sostarek } \\
\text { M }\end{array}$ & $\begin{array}{l}\text { Evaluate the knowledge of general } \\
\text { medical students about treatment } \\
\text { procedures in clinical cases involving } \\
\text { dental injuries. }\end{array}$ & $\begin{array}{l}\text { The study showed that medical students have } \\
\text { very little knowledge about dental injuries. In } \\
\text { addition, the vast majority of students were } \\
\text { neither informed nor educated about it during } \\
\text { their studies. }\end{array}$ \\
\hline 2016 & Azmi M, Awooda E & $\begin{array}{l}\text { Evaluate and compare the knowledge and } \\
\text { practice of } 2 \text { nd and } 5 \text { th year dentistry } \\
\text { students on the management of dental } \\
\text { avulsion. }\end{array}$ & $\begin{array}{l}\text { 5th graders have knowledge considered sufficient } \\
\text { in relation to } 2 \text { nd graders. }\end{array}$ \\
\hline
\end{tabular}




\begin{tabular}{|l|l|l|l|}
\hline 2016 & $\begin{array}{l}\text { Silva BRC, Perazzo MF, } \\
\text { Neves ETB, Firmino RT, } \\
\text { Garcia AFG }\end{array}$ & $\begin{array}{l}\text { Evaluate the effectiveness of an } \\
\text { educational intervention in improving the } \\
\text { level of knowledge about dental avulsion } \\
\text { among non-dental health professionals of } \\
\text { a medical emergency service in Brazil and } \\
\text { the maintenance of this knowledge after a } \\
\text { period of } 6 \text { months. }\end{array}$ & $\begin{array}{l}\text { The educational intervention led to a significant } \\
\text { increase in the number of correct answers } \\
\text { regarding the measures to be taken in cases of } \\
\text { dental avulsion. } \\
\text { The level of knowledge of professionals } \\
\text { remained high } 6 \text { months after the lecture. } \\
\text { However, there was a certain degree of insecurity } \\
\text { the ability to perform the } \\
\text { tegarding } \\
\text { teimplantation. }\end{array}$ \\
\hline 2016 & $\begin{array}{l}\text { Antunes LAA, Souza HMR, } \\
\text { Gonçalves PHPQ, Crespo } \\
\text { MA, Antunes LS }\end{array}$ & $\begin{array}{l}\text { Evaluate the knowledge and attitudes of } \\
\text { physical education students from public } \\
\text { universities in the state of Rio de Janeiro, } \\
\text { Brazil, regarding dental trauma and use of } \\
\text { mouthguards. }\end{array}$ & $\begin{array}{l}\text { Students do not receive such information during } \\
\text { graduation, even having in their curriculum the } \\
\text { discipline of First Aid. }\end{array}$ \\
\hline $\begin{array}{l}\text { Baginska J, Rodakowska E, } \\
\text { Milewski R, Borawsk MW, } \\
\text { Kierklo A }\end{array}$ & $\begin{array}{l}\text { Evaluate the knowledge about first aid in } \\
\text { avulsion of permanent teeth presented by } \\
\text { Polish school nurses from different areas. }\end{array}$ & $\begin{array}{l}\text { The evaluators lack training regarding the } \\
\text { management of dental trauma cases. The Internet } \\
\text { should be used to provide evidence-based } \\
\text { knowledge to medical staff working in schools. }\end{array}$ \\
\hline
\end{tabular}

Source: Authors.

In the database researched, 229 articles were identified, of these, 20 were selected for the study, $11(42 \%)$ involved the classes of dental surgeons (Alaslami, 2018; Azmi and Awooda, 2016; Calle and Vélez, 2019), 6 (23\%) involved doctors or paramedics (Aras and Dogan 2020; Bahammam et al. 2019; Jokic et al. 2017), 7 (27\%) were nurses or nursing assistants (Baginska et al. 2016; Iyer, Panigrahi and Sharma, 2017; Nagata et al. 2018) and 2 (8\%) Physical Educators (Antunes et al. 2016; Sen et al. 2020). Some of them are students still in graduation.

The countries of origin of the studies were distributed as follows: 6 (30\%) Brazil (Antunes et al. 2016; France et al. 2019; Mesquita et al. 2017), 3 (15\%) Turkey (Aras and Dogan 2020; Duruk and Erel, 2020), 3 (15\%) India (Jokic et al. 2017; Kariya et al. 2019; Suganya, Vikneshan and Hirebath 2017), 2 (10\%) Saudi Arabia (Alaslami et al. 2018; Bahammam, 2018) and Croatia (Jokic et al. 2017), United Arab Emirates (Sen et al. 2020), Ecuador (Calle and Vélez, 2019), Pakistan (Viana et al. 2018), Poland (Baginska et al. 2016), Sudan (Azmi and Awooda, 2016) totaled 30\% of studies with one article for each nation. All articles were published in the English language.

In relation to the year of publication, 4 articles were observed for each year of publication between 2016 and 2020.

Of these data presented, all are observational studies, with 19 cross-sectional and one retrospective studies, all aimed at investigating the knowledge about dental avulsion in first aid. Of all the articles reviewed, only three used educational intervention, showing the result of before and after the application of knowledge. About the steps to build the podcast were followed according to the phases of (Figure 2). 
Figure 2 - Characterization of the phases of the elaboration of the podcast called "Al dente". Manaus-AM, 2021

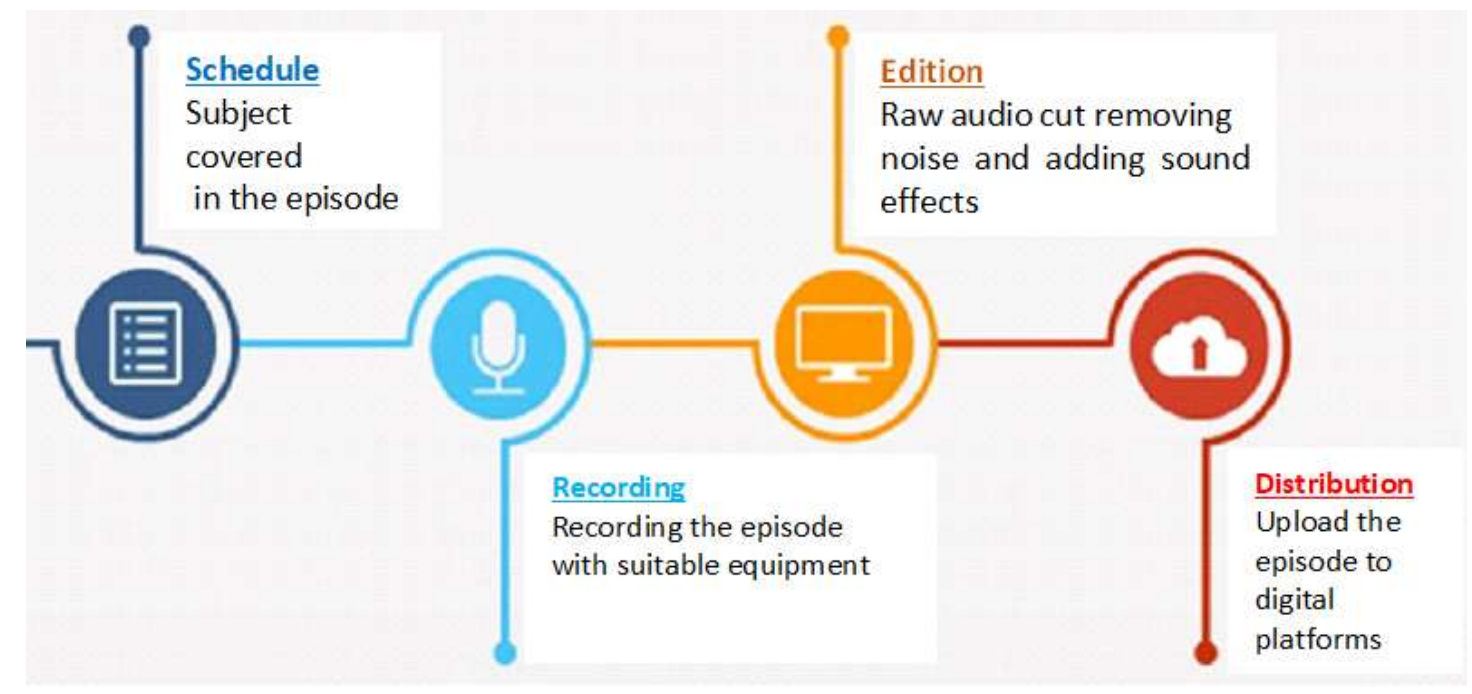

Source: Authors.

The podcast "Al Dente" had the first episode recorded in January 2021, with 11 minutes in length, with the idea of making it easier for listeners to understand. The software used was Adobe Premiere ${ }^{\circledR}$ Pro CC 2020 that made the audio organized and clear, removing overlapping voices and unnecessary parts until the final product. Finally, a cover was made for the media and baptized "Al Dente". With the phases:

Schedule: Definition of the agenda for the construction of the theme/episode approach;

Recording: Organization and execution of the episode with the appropriate equipment;

Edition: Trim raw audio for noise removal and sound insertion;

Distribution: Upload on digital platforms;

Nine expert judges participated in the validation phase, following four aspects: characterization of the judges, content, functionality and appearance.

The expert committee composed of nine judges, had expertise in the area of the content addressed, there was a predominance of males $(66.7 \%)$ and training in surgery and Oral-Maxillofacial Traumatology (66.7\%) and training time with more than 20 years of experience $(55.6 \%)$. There was a tie with respect to the academic qualifications of doctors and Postdoctors $(33.3 \%)$ each, followed by Master's degree (22.2\%) and a specialist. On the expertise with the topic, the judges (100\%) had works published in journals, $(66.6 \%)$ had research projects involving the topic and (66.6\%) had work in Congress, symposia or seminars.

The score of the index was calculated by means of the sum of agreement of the item "strongly agree" marked by the experts and divided by its total amount of answers (Table 1). 
Table 1 - Distribution of judges 'responses content validity of items by topics and individual podcast" Al Dente - Manaus-AM, 2021.

\begin{tabular}{|c|c|c|}
\hline $\begin{array}{l}\text { Objective } \\
\text { Part I }\end{array}$ & $\mathrm{n}$ & $\%$ \\
\hline $\begin{array}{l}\text { 1.1 The information / content is or is consistent with the daily needs of the } \\
\text { target audience }\end{array}$ & 9 & 0.99 \\
\hline $\begin{array}{l}\text { 1.2 Information is important for the quality of the work of the TE target } \\
\text { audience }\end{array}$ & 9 & 0.99 \\
\hline 1.3 Invites and / or instigates attitude behavior change & 6 & 0.66 \\
\hline $\begin{array}{l}\text { 1.4 Can circulate in the scientific environment of the area } \\
\text { Total }\end{array}$ & 6 & $\begin{array}{l}0.66 \\
\mathbf{0 . 8 2}\end{array}$ \\
\hline \multicolumn{2}{|l|}{ Structure and presentation } & \\
\hline 2.1 The educational Podcast is appropriate for the target audience & 9 & 0.99 \\
\hline 2.2 The context is presented clearly and objectively & 7 & 0.77 \\
\hline 2.3 The information presented is scientifically correct & 8 & 0.88 \\
\hline $\begin{array}{l}2.4 \text { The information is appropriate to the socio-cultural level of the TE target } \\
\text { audience }\end{array}$ & 8 & 0.88 \\
\hline 2.5 There is a logical sequence of information & 8 & 0.88 \\
\hline 2.6 The title of the podcast "Al Dente" has coherence & 6 & 0.66 \\
\hline Total & & 0.84 \\
\hline \multicolumn{3}{|l|}{ Relevance } \\
\hline 3.1 The podcast "Al Dente" proposes the construction of knowledge & 9 & 0.99 \\
\hline $\begin{array}{l}3.2 \text { The context addresses the subject necessary for the knowledge of the TE } \\
\text { target audience }\end{array}$ & 9 & 0.99 \\
\hline 3.3 It is suitable to be used by any TE target audience professional & 9 & 0.99 \\
\hline Total & & 0.99 \\
\hline
\end{tabular}

Source: Authors.

It was found that the item that evaluated the objective presented the CVI of $0.82 \%$, structure and presentation $0.84 \%$ and the relevance of the technology with a score $0.99 \%$ which was desirable (Pasquali, 2017; Suganya et al. 2017), characterized by the high index of "strongly agree" among the experts, being the podcast "Al Dente" considered validated in its content.

Regarding the broad evaluation, all the experts evaluated the technology positively, the results showed the IVC of the objectives, the structures and presentation and the relevance obtaining content validity index of $0.88 \%$.

In this sense, we concluded the validation of content with 13 items, throughout the validation process, and presented in the view of the expert's congruence with the literature.

\section{Discussion}

The present study revealed that in different parts of the world, there is a concern with health professionals about the knowledge about dental avulsion and its correct conduct for reimplantation. 
A study conducted in Brazil in 2020, when comparing the knowledge about dental avulsion among students of Dentistry, Nursing and medicine, dental students presented the highest percentage in all the questions evaluated, this is due to the fact that dental students have this information in their curriculum (Polit and Beck, 2011).

When analyzing the professional General Dental Surgeons in 2019 in Paraná, Brazil, they showed that they did not have good knowledge about the procedures to be adopted for the reimplantation of avulsified teeth (France et al. 2019). When comparing studies carried out in Istanbul, Turkey (Rodrigues et al. 2020), 142 dentists were evaluated and of these only 35\% remember what to do in the face of a case of dental avulsion, which shows us the importance of continuing education programs.

Another evaluation with dentists carried out in Turkey, involving 400 general professionals and specialists, concluded that pediatric dentists had greater knowledge in the case, that of giving to the fact that it is the specialty that most studied cases of dental avulsion during their education in relation to other specialties (Duruk and Erel, 2020). There is a situation as in the study conducted with 143 dentists in the city of Cuenca, Ecuador in 2019, in which $42 \%$ reported having minimal knowledge about dental trauma and $74.8 \%$ of respondents are not familiar with the recommended IADT protocols for conducting dental trauma (Calle and Vélez, 2019).

Numerous articles conducted in different countries show doctors, paramedics, nurses, nursing assistants and physical educators, who do not have adequate knowledge about managing a dental avulsion emergency (Antune et al. 2016; Aras and Dogon, 2020; Baginska et al. 2016; Bahammam, 2018). Victims of oral trauma seek immediate care, at the scene of the accident or in hospitals and emergency rooms, which put these professionals in front of a line of action to provide the primary care of these cases.

Evaluating 150 doctors in different hospitals in Jeddah, Saudi Arabia, showed 79.5\% of professionals, they thought it was possible to reimplant the avulsified tooth, however, $51.6 \%$ of them would not do it alone (Bahammam, 2018). This insecurity was shown in the other studies. In Turkey, $86.4 \%$ of the 389 doctors and paramedics interviewed did not receive any training on dental trauma, which corroborated that $75.6 \%$ believe that an avulsified tooth cannot be reimplanted (Aras and Dogon, 2020).

However, the research carried out involving the effect of an educational intervention on the subject, revealed a positive impact on the acquisition of knowledge about emergency procedures, especially in cases of avulsion. Educational programs should be developed for health professionals in order to encourage them to properly conduct an emergency episode of a dental trauma (Nagata et al. 2018; Sen et al. 2020; Sari et al. 2019).

In Brazil, the effectiveness of an educational intervention for doctors and nurses was also evaluated and led to a significant increase in the number of correct answers on the measures to be taken in these cases. In addition, the level of knowledge remained high six months after the lecture (Sari et al. 2019).

It is unquestionable that educational technologies should be built in order to provide information about dental reimplantation.

The content of the podcast was based on the recommended guidelines of the International Association of Dental Traumatology - IADT, which is a consensus document carried out by a group of international researchers, obeying scientific criteria, therefore guidelines with knowledge capable of subsidizing safe practices on the management of permanent avulsified teeth (Fouad et al. 2020).

As for the content validity Index (IVC), it was considered adequate by the experts without any correction, considering that they were given the right to general comments and suggestions at the end of each form. The content evaluated revealed a high CVI value, with an excellent level of agreement among experts, suggesting that the content has relevance in the subject of timely conduction after a dental avulsion in permanent teeth. The use of the CVI for experts in the area of the subject 
addressed, has been carried out by researchers in the evaluation of technologies in several works found in other studies on educational technologies (Netoet al. 2019; Suganya, Vikneshan and Hirebath, 2017).

\section{Conclusion}

The results of the technology validated in three aspects of the objective, structure, presentation and relevance items after reaching a 99\% CVI by the judges. These data show that technology with a focus on knowledge about the conduct of dental reimplantation in permanent teeth, is necessary for a successful prognosis.

Technological production can contribute to the reflection and decision making of the dental surgeon in the care practice in oral traumatisms.

As future perspectives, the dentist will be able to propose other technologies such as the podcast with didactic potential, facilitating and motivating learning in cases of dental traumatology.

\section{Acknowledgments}

The authors would like to thank the State University of Amazonas through the Specialization Course in Technology and Innovation in Health, in addition to the support of the Laboratory of Technology in Health and Education -LABTECS for the support granted for the development of this research.

\section{References}

Al Sari, S., Kowash, M., Hussein, I., \& Al-Halabi, M. (2019). An Educational Initiative for Dubai School Nurses and Physical Education Teachers on the Management of Traumatic Dental Injuries. The Journal of School Nursing, 35(5), 359-366. https://doi.org/10.1177/1059840518780306.

Alaslami, R. A., Elshamy, F., Maamar, E. M., \& Ghazwani, Y. H. (2018). Awareness about Management of Tooth Avulsion among Dentists in Jazan, Saudi Arabia. Open access Macedonian journal of medical sciences, 6(9), 1712-1715. https://doi.org/10.3889/oamjms.2018.299

Andreasen, J. O., Andreasen, F. M., \& Andersson, L. (2018). Textbook and Color Atlas of Traumatic Injuries to the Teeth (5 th ed.). Wiley-Blackwell.

Antunes, L. A. A., Souza, H. M. R. D., Gonçalves, P. H. P. D. Q., Crespo, M. A., \& Antunes, L. S. (2016). Trauma dental e protetor bucal: conhecimento e atitudes em estudantes de graduação em Educação Física. Revista Brasileira De Educação Física E Esporte, 30(2), 287-294. https://doi.org/10.1590/180755092016000200287

Aras, A., \& Dogan, M. S. (2020). Evaluating the levels of knowledge and attitudes of emergency medical technicians and paramedics toward traumatic dental injuries. Nigerian journal of clinical practice, 23(1), 54-58. https://doi.org/10.4103/njcp.njcp_257_19

Awooda, Elhadi. (2016). Knowledge of emergency management of avulsed tooth among undergraduate preclinical and clinical dental students: Questionnaire-based study. Journal of Dental Research and Review. 3. 140-143. https://doi.org/10.4103/2348-2915.200014.

Baginska, J., Rodakowska, E., Milewski, R., Wilczynska-Borawska, M., \& Kierklo, A. (2016). Polish school nurses' knowledge of the first-aid in tooth avulsion of permanent teeth. BMC Oral Health, 16(1). https://doi.org/10.1186/s12903-016-0183-2.

Bahammam, L. A. (2018). Knowledge and attitude of emergency physician about the emergency management of tooth avulsion. BMC Oral Health, 18(1). https://doi.org/10.1186/s12903-018-0515-5.

Cruz-da-Silva, B. R., Perazzo, M., Neves, É. T., Firmino, R. T., \& Granville-Garcia, A. F. (2016). Effect of an Educational Programme on the Knowledge Level Among an Emergency Service Medical Team Regarding Tooth Avulsion. Oral health \& preventive dentistry, 14(3), 259-266. https://doi.org/10.3290/j.ohpd.a35615.

Duruk, G., \& Erel, Z. B. (2020). Assessment of Turkish dentists' knowledge about managing avulsed teeth. Dental Traumatology, 36(4), 371-381. https://doi.org/10.1111/edt.12543.

Fouad, A. F., Abbott, P. V., Tsilingaridis, G., Cohenca, N., Lauridsen, E., Bourguignon, C., O'Connell, A., Flores, M. T., Day, P. F., Hicks, L., Andreasen, J. O., Cehreli, Z. C., Harlamb, S., Kahler, B., Oginni, A., Semper, M., \& Levin, L.. (2020). International Association of Dental Traumatology guidelines for the management of traumatic dental injuries: 2. Avulsion of permanent teeth. Dental Traumatology, 36(4), 331-342. https://doi.org/10.1111/edt.12573.

França, A. B., Neves, A. C. D. S., Queiroz, A. F., Poi, W. R., \& Hidalgo, M. M. (2019). Evaluation of dentists' knowledge on urgency conduct for avulsed teeth. Acta Scientiarum. Health Sciences, 41, e44400. https://doi.org/10.4025/actascihealthsci.v41i1.44400.

Galindo-Neto, N. M., Alexandre, A. C. S., Barros, L. M., Sá, G. G. D. M., Carvalho, K. M. D., \& Caetano, J. Á. (2019). Creation and validation of an educational video for deaf people about cardiopulmonary resuscitation. Revista Latino-americana De Enfermagem, 27(0). https://doi.org/10.1590/15188345.2765.3130. 
Galvão, A. K., Cabral, G. M., Miranda, A. F., Baeder, F. M., \& Santos, M. T. (2020). Tooth avulsion accidents due to urgent and emergency orotracheal intubation. Medicina oral, patologia oral y cirugia bucal, 25(3), e353-e358. https://doi.org/10.4317/medoral.23375

Ivancic Jokic, N., Bakarcic, D., Grzic, R., Majstorovic, M., \& Sostarek, M. (2016). What general medicine students of University of Rijeka know about dental avulsion? European Journal of Dental Education, 21(4), e131-e134. https://doi.org/10.1111/eje.12235.

Iyer, S. S., Panigrahi, A., \& Sharma, S. (2017). Knowledge and Awareness of First Aid of Avulsed Tooth among Physicians and Nurses of Hospital Emergency Department. Journal of pharmacy \& bioallied sciences, 9(2), 94-98. https://doi.org/10.4103/jpbs.JPBS_343_1.

Jain,A.Kulkarni,P.Kumar,S.Jain,M.(2017).Knowledge and Attitude of Parents towards Avulsed Permanent Tooth of their Children and its Emergency Management in Bhopal City, 11(5), ZC40-ZC44. https://www.doi.org/10.7860/JCDR/2017/24953/9855.

Kariya, P. B., Singh, S., Bargale, S., Shah, S., Kulkarni, N., \& Dave, B. H. (2019). Evaluation of knowledge regarding emergency management of avulsed traumatic dental injuries in children among general dental practitioners in India. Indian journal of dental research: official publication of Indian Society for Dental Research, 30(1), 21-26. https://doi.org/10.4103/ijdr.IJDR_807_16

Mesquita, G. C., Soares, P. B. F., Moura, C. C. G., Roscoe, M. G., Paiva, S. M., \& Soares, C. J. (2017). A 12-Year Retrospective Study of Avulsion Cases in a Public Brazilian Dental Trauma Service. Brazilian Dental Journal, 28(6), 749-756. https://doi.org/10.1590/0103-6440201701610.

Nagata, J. Y., Góis, V., Münchow, E. A., \& Albuquerque, M. (2018). Dental trauma education intervention as a positive influence among undergraduate students. European journal of dentistry, 12(4), 502-507. https://doi.org/10.4103/ejd.ejd_148_18.

Pasquali, L. (2017) Validade dos Testes. Revista Examen. 1(1):14-48.

Polit, D.F.; Beck, C.T. (2011) Fundamentos de pesquisa em enfermagem: métodos, avaliação e utilização. (7th ed.), Artmed.

Rodrigues, O. F. E., Landim, K. L. G., Alves, R. T., Machado, F. C., \& Carrada, C. F. (2021). Knowledge of Avulsion of Permanent Teeth Emergency Management Among Undergraduate in Brazilian Health Care Students. Pesquisa Brasileira Em Odontopediatria E Clínica Integrada, 21. https://doi.org/10.1590/pboci.2021.015.

Sen Yavuz, B., Sadikoglu, S., Sezer, B., Toumba, J., \& Kargul, B. (2020). An Assessment of the Knowledge of Dentists on the Emergency Management of Avulsed Teeth. Acta stomatologica Croatica, 54(2), 136-146. https://doi.org/10.15644/asc54/2/3

Suganya, M., Vikneshan, M., \& Hiremath, A. (2016). Timely management of knocked out teeth - are the nurses aware? Journal of Clinical Nursing, 26(9-10), 1257-1263. https://doi.org/10.1111/jocn.13525.

Tapia-Calle, J., \& Pinos-Vélez, K. (2019). Conocimiento del manejo de la avulsión dental entre dentistas en Cuenca, Ecuador. Maskana, 10(1), 35-39. https://doi.org/10.18537/mskn.10.01.05.

Vianna, L. R. V., Barreto, M. M. B., Girard, C. C. P. G., \& Teixeira, E. T. (2018). Tecnologia educacional para mediar prátic as educativas sobre alimentação complementar na amazônia: Estudo de validação. Revista Lbérica de Sistemas y Tecnologías de Información, 28(3), 29-40. https://pdfs.semanticscholar.org/3446/2c1b791227d62cce17aac8973f0e392d2097.pdf

Zafar, K., Ghafoor, R., Khan, F. R., \& Hameed, M. H. (2018). Awareness of dentists regarding immediate management of dental avulsion: Knowledge, Attitude, and Practice study. JPMA. The Journal of the Pakistan Medical Association, 68(4), 595-599. 